Article

\title{
'Four Populisms' of Alexey Navalny: An Analysis of Russian Non-Systemic Opposition Discourse on YouTube
}

\author{
Sofya Glazunova \\ Digital Media Research Centre, Queensland University of Technology, Brisbane, QLD 4059, Australia; \\ E-Mail: s.glazunova@qut.edu.au
}

Submitted: 16 April 2020 | Accepted: 12 July 2020 | Published: 15 October 2020

\begin{abstract}
The rise of populist movements across the globe has instigated considerable research interest into populism, predominantly in Western democracies. Non-democratic Russia, however, is not exempt from this populist trend, and distinguishable populist rhetoric can be observed both inside and outside the establishment. Alexey Navalny, who regularly organises mass protests in Russia, is considered to be an outsider of systemic politics. Despite several unsuccessful attempts to be elected, his popularity continues to grow, largely due to digital instruments such as YouTube. In light of limited press freedom, YouTube has become one of the most trustworthy platforms for Navalny to publish his investigative documentaries about Russian corruption. In his videos, Navalny adopts a populist communication style to oppose himself to Putin's 'corrupt' elite. Different investigative journalism practices help Navalny to discredit the establishment, whereas his activist appeals may motivate his supporters to engage in political action. In this article, I explore how Navalny combines the practices of investigative journalism and civic activism in his populist communication on YouTube. Using the method of content analysis, I explore a case study of Navalny's YouTube communication and reveal four types of populism which play a special role in his narration. These are 'superficial,' 'investigative,' 'radical,' and 'advocacy' populisms. Advocacy populism, for instance, provides evidence of corruption elite crimes through journalism practices and in calling people to political action. The most visible concentration of these parts of narration was observed in YouTube videos released by the activist before and during anti-corruption protests of 2017.
\end{abstract}

\section{Keywords}

corruption; digital activism; investigative journalism; opposition; populism; press freedom; YouTube

Issue

This article is part of the issue "Freedom of Expression, Democratic Discourse and the Social Media" edited by Maria Elliot (Linnaeus University, Sweden) and Kristoffer Holt (Linnaeus University, Sweden).

(C) 2020 by the author; licensee Cogitatio (Lisbon, Portugal). This article is licensed under a Creative Commons Attribution 4.0 International License (CC BY).

\section{Introduction}

2021 marks three decades since the Soviet Union dissolution, which has changed the political trajectories of all countries of the former Soviet bloc. Russia, as a successor of the Soviet Union, has undergone several political transformations since, including changes in its communication about politics. The relative press freedom in postGlasnost Russia increased transparency in political communication (PC) from 1986 to the 1990s. However, after the Soviet structure's dissolution this openness was progressively curtailed. It was replaced by limited freedom of speech, elimination, harassment, as well as censorship of dissident journalists and media (Becker, 2004).

A growth in authoritarian tendencies in Russia has been well-documented in 2019 (Repucci, 2019). While undoubtedly a matter of concerns for some, it has also led to the emergence of new hybrid communication projects that oppose mainstream narratives using digital technologies. Opposition leader Alexey Navalny stands exemplar of someone who creatively uses communication tools and populist discourses to challenge the dominant political elite-a strategy he has employed since rising to popularity in the 2010s (Gel'man, 2015). 
Navalny established himself as a key oppositional figure during the mass protests of 2011-2012, which occurred in response to Russia's parliamentary and presidential elections. The various opposition forces united then towards two common goals: the reconsideration of the parliamentary election results and the resignation of high-ranking officials. Among prominent figures at the protests were activists such as Nemtsov, Kasyanov, Dmitry and Gennady Gudkovs, and Navalny himself. The enthusiasm of protesters and activists quickly faded as protesters realised they were far from succeeding their goals (Gel'man, 2015). Due to harassment, most of these opposition figures have been less prominent in the public sphere of the 2010s than Navalny. He managed to remain a popular, 'non-systemic' politician in Russiain essence, a non-elected politician operating outside of the political system.

Despite frequent harassment, Navalny published numerous journalistic investigations of Russian politicians' corruption on his social media platforms - an act which resonated across several publics. These were the investigations into the corruption cases of Russian General Prosecutor Chaika, businessman Deripaska and former Deputy PM Prihod'ko and others. The most resonant documentary on his channel about former Prime Minister (PM) Medvedev led to several large-scale protests across major Russian metropoles in 2017. These were the first regular, mass anti-government protests to occurreminiscent of the events in 2011-2012. Unlike his opposition colleagues, Navalny managed to secure a communication strategy of attracting anti-government movement supporters, which involved different communication instruments.

This article addresses the following research question: how does Navalny combine practices of investigative journalism (IJ) and digital activism in his populist communication on YouTube? The text transcripts of Navalny's YouTube videos containing these practices, released during his campaign for the 2018 presidential election, are studied through the method of content analysis. In addition to the narration, which can be considered as one of the representations of political performance (Rai, 2015), the visual aesthetics of stage, body politics (clothing style), and colour of Navalny's YouTube populist performance are explored elsewhere (Glazunova, 2020).

This case study contributes to the evolving corpus of literature on digital media in PC of authoritarian and semi-authoritarian countries. Social media is seen as a more flexible, provoking, and transformative space for diversified communication, particularly in light of limited press freedom.

\section{Political Communication Shifts}

Research into Navalny's communication is situated in the field of PC. At its most basic level, PC is purposeful communication about politics involving different interest groups. As a phenomenon, it has significantly changed in the 21st century, where many shifts are currently being observed. Three of them have a direct relation to Navalny's communication. Firstly, according to Blumler (2013), we now live in an age characterised by the extensive use of Internet facilities in communication, where newly emerged social media platforms have 'shaken' the established rules of PC. Secondly, in this new PC environment, trust in news media and global press freedom continues to decline (Newman, Fletcher, Kalogeropoulos, \& Nielsen, 2019; Repucci, 2019). Investigative reporting can play a 'watchdog' role in society, where general coverage of mainstream media fails to follow democratic principles of unbiased and transparent coverage. Lastly, many politicians have started to spread populist messages increasingly, emphasising the purported antagonism between two populist entities of 'the people' vs. 'the elite' in them. Navalny stands out as a prominent example of these observed changes in Russia's PC.

\subsection{Digital Media as an Emergent Actor of Political Communication}

Citizens, media, and actors seeking political power are considered the major PC actors in exchanging political messages (McNair, 2011). Their history can be traced back for hundreds of years. New actors such as social media platforms appeared later, in the Internet-abundant age of PC (Blumler, 2013). Kaplan and Haenlein (2010, p. 61) defined 'social media' as "a group of Internetbased applications that build on the ideological and technological foundations of Web 2.0 and that allow the creation and exchange of user-generated content." Social media can be considered as a separate actor of PC, following the logic of Schrape (2016, p. 13), who stipulates that "the character limit on Twitter or the algorithmic curation on these social networking platforms as well as on media streaming portals...are not just technical gimmicks but rather social structure elements that are incorporated in the platform design." These social structure elements can play a crucial role in communication about politics.

One of the prominent areas of the research of social media and politics is in the field of digital activism and social movements. In Russia, for example, during the 2011-2012 protests 'for fair elections,' it was found that platforms like Facebook mostly helped to mobilise supporters for the anti-regime demonstrations (White \& McAllister, 2014). Nevertheless, the Russian government was also effective in countering protests with information and communications technologies (Spaiser, Chadefaux, Donnay, Russmann, \& Helbing, 2017). Notably, these protests were a trigger for the government to further regulate mainstream media and online spaces. Opposition figures like Navalny, who are unsuccessful in being elected, continue to operate from the 'ghetto' (Gel'man, 2013); deploying alternative digital communication instruments including YouTube channels. 
Launched in 2005, YouTube (later a Google subsidiary) quickly became the dominant platform in the global social media market (Burgess \& Green, 2018). In 2019, YouTube was the most popular digital platform in Russia (Statista, 2019). As a consequence of the declining trust in Russian mainstream media-and TV in particular (FOM, 2018)-YouTube has also become an alternative news medium for Russians, promoting "visually motivated, amateur-driven news culture that alters the truth claims of news and the professional hegemony of news making" (Sumiala \& Tikka, 2013, p. 318). In Russia, YouTube gives a voice to amateur, grassroots, citizen, and investigative journalists such as Navalny, who expose corruption and power abuse in the country.

\subsection{Investigative Journalism and Its Watchdog Role}

In its 2019 report, Freedom House (Repucci, 2019) observed a global trend of declining press freedom. In authoritarian or semi-authoritarian regimes, who are fuelling this decline (such as Russia), the toolbox of media regulation by the state includes: government-backed ownership takeovers, threats against journalists, licensing practices abuse, and other measures (Repucci, 2019). As a result, the need for quality, watchdog IJ arises, which may contribute to challenging the status quo coverage of politics.

To be identified as falling within the investigative genre, a story should be centred on the public interest "by exposing abuses of power in society" (Carson, 2019, p. 65). Moreover, IJ always requires greater time, money, and effort from journalists compared to less complex journalistic genres of conducting investigations (Carson, 2019, p. 66). De Burgh (2008, p. 16) calls these journalistic skills 'desk skills,' meaning that journalists should have "the thorough knowledge of information sources and types and the rules that govern them, the ability to read documents for significance, and an understanding of statistics." In addition, journalists would need to apply a higher level of scrutiny, verify facts, and look for legitimate sources of information (Carson, 2019 , p. 66). Journalists are believed to have a hierarchy of evidence, where each information source has its own weight (Ettema \& Glasser, 1984, p. 17). The prominent display of collected 'evidence' is considered in this article as one of the crucial indicators of $\mathrm{IJ}$ in Navalny's performance.

In a digitised world, journalists need to adapt to new sources, instruments, and channels of information. Depending on the instruments, new sub-types of IJ have emerged; including data journalism, drone journalism, and others types. Data journalism, for example, is "a form of storytelling where traditional journalistic working methods are mixed with data analysis, programming, and visualisation techniques" (Nygren, Appelgren, \& Hüttenrauch, 2012, as cited in Appelgren \& Nygren, 2014 , p. 394). Famous cases of cross-national investigations such as the Panama Papers showed that big data leaks followed by a concerted effort of journalists working across borders, can help to hold politicians and governments accountable (Carson, 2019).

In the post-Communist countries of Eastern Europe, which Russia is closer to in a political and cultural sense, watchdog reporting operates in a state where "the already resource-weak news organisations" become "even weaker" (Stetka \& Örnebring, 2013, p. 414). Stetka and Örnebring (2013) suggest that the number of investigative journalists in the country tends to be correlated to the level of media freedom observed; the freer the media, the higher the number of investigative journalists. They distinguished two major types of IJ in Eastern Europe: mainstream media organisations, as well as Internet-based outlets and projects. The second type of journalism was represented in Bulgaria, Hungary, Latvia, and Romania, countries with 'partly-free' press at that time (Stetka \& Örnebring, 2013).

Russian critical journalists, in turn, associate themselves with opposition and propagate freedom of speech (Repnikova, 2018). The examples of relatively liberal or oppositional outlets include, e.g., the online newspaper Meduza (whose headquarters are located in Latvia) and the newspaper Novaya Gazeta, known for its high-profile investigations about political topics. Navalny's engagement on YouTube can be considered as a unique and alternative media project that can potentially contribute to a watchdog role of journalism in the country-combining investigative reporting practices with a call to collective political action for invoking systemic change. In countries with limited press freedom, activists and independent journalists may need to pursue two political goals simultaneously: to overcome restrictions on media freedom and to advocate their essential political rights.

Furthermore, Houston (2010, p. 45) notes that IJ is inherently populist and adversarial in its nature, "challenging the powers that be." By exposing the power abuse and corruption of the 'villains,' protecting the 'victims' (Carson, 2019) and their public interest by sometimes more radically inviting people to action, IJ shares an intersection with populism that is based on the antagonism of 'the people' and 'the elite.' As this article will continue to demonstrate, Navalny has skilfully made use of this intersection for his political purposes.

\subsection{Rise of Populist Narratives}

There are diverse ways of defining populism. Different scholars understand populism as an ideology (Mudde, 2004), a logic (Laclau, 2005), a discourse (Laclau \& Mouffe, 1985), a philosophy (Inglehart \& Norris, 2016), and a political style (Moffitt \& Tormey, 2014) among others. I follow de Vreese, Esser, Aalberg, Reinemann, and Stayner's (2018) notion, which distinguish between the 'style' and the 'content' of populism. The former is "a set of presentational style elements," while the latter is "public communication of core components of populist ideology (such as people-centrism and anti-elitism)" 
(de Vreese et al., 2018, p. 425). This definition allows for measuring degrees of populism in discourses (de Vreese et al., 2018, p. 426), which aligns with this article's objectives.

In this study, I focus on Navalny's populist ideological content. Most authors understand people-centrism as referring to 'the people,' where 'people' are the primary source of legitimate power (Bonikowski \& Gidron, 2016) and sovereignty (Jagers \& Walgrave, 2007; Moffitt \& Tormey, 2014). Using this style of communication, populists associate themselves with 'the people' by appealing or referring to them. This project focusses specifically on the empirical indicators of 'the people' in texts that are often represented by pronouns like 'we' and 'us.' In critical discourse analysis, the use of such pronouns is explained by the desire of the politician "to assimilate 'the people' to the leader, or the leadership" (Fairclough, 2001, p. 180). Addressing the people can also be expressed through mass nouns such as 'people,' 'citizens,' 'voters,' 'taxpayers,' and others.

The populist appeal is distinctly political. Politicians addressing 'the people' usually want some form of direct or indirect action from them. They want citizens to vote in someone's favour, to protest, to disseminate information, and conduct other actions. This 'call to action' is a radical form of appeal to 'the people' in populist communications, and it can be vital to the success of increasing political participation among audiences.

Anti-elitism is another central element of populism. The typical anti-elite descriptions within populism state that elites are distant from 'the people,' associated with the external enemy ('us' vs. 'them'), politically incompetent, and indifferent to the public interest-in effect; saboteurs, corruptors, and betrayers of public trust (Bonikowski \& Gidron, 2016; Jagers \& Walgrave, 2007). Populists can refer to the elite more generally with collective pronouns and nouns such as 'they,' 'the government,' 'the establishment,' and 'the elite' - but they can also target particular individuals, groups of people, and institutions of political power. In Navalny's communication, it is clear that populists can discredit elites. They can simply bring them into disrepute by using words such as 'crooks' and 'thieves,' or by providing arguments and purported evidence of elites' crimes and misconduct. In the latter case, investigative and advocacy journalists also use evidence to expose the 'villains.'

Navalny uses an investigative genre; employing some evidence of corruption found on social media, the Internet, and other sources to expose Putin's elite. He also publishes predominately on digital channels, which reflects Gerbaudo's (2017) idea of 'cyber-populism' that enables spaces via digital media platforms (free from the state), where citizens can gather and be mobilised for political action. Gerbaudo (2018, p. 746$)$ argues that social media platforms "have offered a channel for the populist yearning to 'represent the unrepresented."' Among these platforms, YouTube is still overlooked in populism research on 'political' Facebook and Twitter represented by studies such as Engesser, Ernst, Esser, and Büchel (2017), Waisbord and Amado (2017), Jacobs, Sandberg, and Spierings (2019), and others. However, the performative, participative, and sometimes radical nature of the platform allows for creating and spreading populist counter-narratives in countries like Russia.

Finally, Navalny's ideas exist within the framework of authentic Russian populism. The first mentions of populism in the Russian context were connected with the movement of Narodniks ('narod' means 'people' in Russian) in the late 19th-early 20th centuries. Russian intellectual classes in the late 19th century practised what is known as 'goings to the people.' They visited ordinary peasants in villages, propagated distrust in religion, rebuked the authority of the tsar and denounced samoderzhavie (autocracy). Modern Russian politicians oppose their counter-elite and seek active feedback from voters. The distinction of 'us' and 'them' in Putin's rhetoric has gone several transformations. 'Them' has previously referred to terrorists, the West and the US in particular; now it is applied to the opposing liberals referred to as 'Fifth Column' (Kolesnikov, Kortunov, \& Snegovaya, 2018). The opposition movement of 2011-2012 has also resorted to populist rhetoric in their struggle against Putin's regime (Gel'man, 2015). The latter, as Gel'man (2015) argued, contributed to the re-birth of Russian opposition in the beginning of the 2010s, during the protests when the opposition project of Navalny emerged.

\section{Alexey Navalny and the Russian Political Communication Ecosphere}

The protests 'for fair elections' led to further restrictions of citizens' political rights, mass media, and the Internet introduced by the Russian establishment. Mainstream media started to be further controlled by a mixture of business and administrative measures - a process that has started back in the 1990s (Becker, 2004). The Internet was usually acknowledged as a freer space for alternative political discourses in Russia (Etling, Alexanyan, Kelly, Farris, \& Gasser, 2010). However, the Agora (2018) report states that in 2017, 244 webpages in the RuNet (Russian Internet) were blocked every day, every six days users were harassed or threatened, and every eight days Russian courts sentenced someone to prison in relation to 'misbehaviour' on the Internet (Agora, 2018).

In this environment Navalny's popularity continues to grow, despite his status as an outsider of systemic politics. (Levada, 2017). At the beginning of 2020, his personal blog on YouTube had more than three million subscribers. Several strategies could be observed in his communication with audiences. Firstly, Navalny was still using populist strategies in his rhetoric, apparent since 2011. His recent populist performances echo the activities of Russian populism's founding fathers-Narodnik's movement. To promote anti-establishment sentiments in a contemporary context, Navalny releases a YouTube 
video using similar rhetoric instead of physical 'goings to the people.'

Secondly, he extensively employs digital instruments in communicating his message to a peripheral electorate. YouTube is not the only platform that the activist and his team use for communication. However, among all of them, YouTube stands as a relatively free medium that reaches a broad audience across Russia and affords opportunities to contest the regime. Facebook, Twitter, and Google with its subsidiary YouTube (all major international technology companies) are still relatively capable of resisting the RuNet regulations according to an Agora (2019) report. Finally, the format of investigations that Navalny uses for his videos reaches the highest viewership on his channel. As of June 2020, the most popular videos on his channel are investigations into corruption of the former PM (34 million views), the General Prosecutor (12 million views), North Caucasus officials (11 million views), and others. As this article has argued, these strategies can contribute to securing his survival in the Russian public sphere.

\section{Methodology}

\subsection{Methods}

This article investigates the case study of populist communication of Alexey Navalny using the method of content analysis. The method was used historically for the investigation of media texts, or to "yield inferences from all kinds of verbal, pictorial, symbolic, and communication data" (Krippendorff, 2004, p. 17). As I work with Navalny's communication and conversational data (namely videos and deriving from them texts that require rearticulating or reinterpretation of the messages to understand Navalny's phenomenon better), content analysis is the most suitable research method for this study.

Krippendorff (2012) doubts the dichotomy of qualitative and quantitative content analyses. He notes that "all reading of texts is qualitative by nature," and using computers to analyse them does not make them any less qualitative (p. 22). The qualitative dimension of content analysis is sometimes called 'interpretive' (Krippendorff, 2004, p. 17). Through the close reading of "relatively small amounts of textual matter" (Krippendorff, 2004, p. 17), interpretation of texts into new narratives, and culturally conditioned understandings, new inferences of the text are drawn, with new meanings depending perhaps on the theoretical lens. In this research, the quantitative part helped to answer what words and how often they occurred, whereas the qualitative part-through a process of close reading-involved interpreting and contextualising Navalny's communication phenomenon.

The drawbacks of measuring populism by content analysis were described by Pauwels (2011). They include high labour intensity, coder subjectivity, and unreliability (Pauwels, 2011, p. 98). This project addresses these issues, including the ambiguity of the populist phenomenon and the distinctive political context that frames Navalny's communication.

\subsection{Data}

The main data consisted of Navalny's YouTube videos in transcript form. His channel has existed since 2013. However, I was interested in more recent communications of the activist, connected primarily to his presidential electoral campaign (from December 13, 2016, until the fourth inauguration of President Putin on May 7, 2018). This was the period during which Navalny was most active, thus containing the maximum concentration of posts, including his major investigations on Russian corruption. In these 18 months, Navalny posted 150 videos of varying length. I purposefully shortlisted his most viewed videos, which potentially can have a bigger impact on the audience through their reach; i.e., those above the median of $1,600,000$ views. This resulted in 77 videos selected for the sample.

All of the 77 videos were narrated in the Russian language. The total number of words in the selected sample is 83,023 words. The total time length of the selected video sample is 10 hours, 43 minutes, and 7 seconds. The shortest video is 46 seconds long, where Navalny addresses his audience from Simonov's Court. The longest video is 49 minutes and 38 seconds and describes the investigation into corruption of the former Russian PM.

Parts of the videos where Navalny narrated directly to the camera were most prevalent across the videos. However, his videos were frequently interspersed with content from other people's speeches into the narrative structure. For this research, I chose the excerpts that contain only Navalny's direct speech (narration). In total, 331 excerpts among the 77 most viewed videos were identified and subsequently coded in content analysis software NVivo.

\subsection{Coding Categories}

To ensure a nuanced understanding of Navalny's narration, four coding categories were developed. The two main categories for coding, 'appeal to the people' and 'discrediting the elites' as explained in Section 2.3, were subdivided into two further categories each. An 'appeal to the people' was sub-categorised based on the way the appeal to 'the people' was communicated, as well as the level of radicalisation of the populist call, distinguishing between the categories 'simple addressing' and 'call to action.' The category 'discrediting the elites' was split into 'empty discrediting' and 'discrediting with evidence' to explore the presence of journalistic investigation practices that Navalny uses to discredit elites. Therefore, a total of four categories were coded in the excerpts.

'Simple addressing' is a process where a politician (Navalny specifically) is merely talking to people and invites them to a conversation through the video. He addresses them to associate himself with the audience. In 
this case, he does not invite them to a political or another form of action. He uses simple addressing forms using the pronouns 'we' and 'us' as part of the narration (example: "Putin studiously ignores us, he keeps repeating that we don't have any propositions or a constructive agenda").

'Call to action' is a radical form of appealing to the people, including an invitation to political action. The call presupposes the subsequent action the populist communicator expects from the audience expressed in action verbs (e.g., to boycott, to vote). A narrator might use the imperative mood to indicate motivating or mobilising supporters around his/her political goals. The excerpts containing a 'call to action' contain 'simple addressing,' too. This overlapping is explained by the fact that in calling people to action, a communicator can use simple words like 'we' and 'us' which are considered as simple forms of addressing people (example: "On May 5th, I urge all of you to participate in demonstrations, rallies and protests for our right to be the citizens of our country").

'Empty discrediting' is the attempt of a populist to discredit elites, yet this attempt is merely an allegation not supported by evidence, and consists of accusations and denigrations of those who form part of the elite (e.g., calling someone a 'crook' or a 'thief'). In this project, to 'discredit' is understood as ceasing to respect someone or believing an idea or person (example: "Only we can oppose this ghoul who's dragging us into poverty and turning Russia into a third world country, just so he can stay in charge and keep getting that fake percentage").

'Discrediting with evidence' is the attempt to discredit the elite through claims that are supported by ev- idence of a journalistic format, including materials from social media, websites, official documents of the government, and other types of evidence. A narrator should refer to them in his/her texts. 'Discrediting with evidence' a priori contains the category 'empty discrediting,' as Navalny uses words denigrating the elite (e.g., 'crooks,' 'thieves'), but also provides evidence collected through journalistic practices in the same excerpt (example: "While I do it, we'll also entertain you with some footage of Usmanov's mansion, so you'll get a chance to see how Russian oligarchs live").

Thus, four categories of the ideological content of populism are presented in Figure 1. According to the description of the categories and Figure 1, there were overlapping categories, such as a 'call to action' containing forms of 'simple addressing' as well as 'discrediting with evidence' which consists of 'empty discrediting.' Both coders involved in the process considered those facts but counted only unique and dual combinations of the four categories in the sample, as Table 1 will further demonstrate.

\subsection{Reliability}

To reach an inter-coder agreement, another Russian speaker was consulted for the coding process. However, Coder 2 did not need a full sample of the excerpts; it could be reached through a representative sub-sample calculated via a specific formula. The agreement was reached through a representative sub-sample calculated using Riffe, Lacy, and Fico's (2014, p. 111) formula as seen in Figure 2. This resulted in a sub-sample of 89 excerpts, chosen randomly out of the aforementioned total of 331.

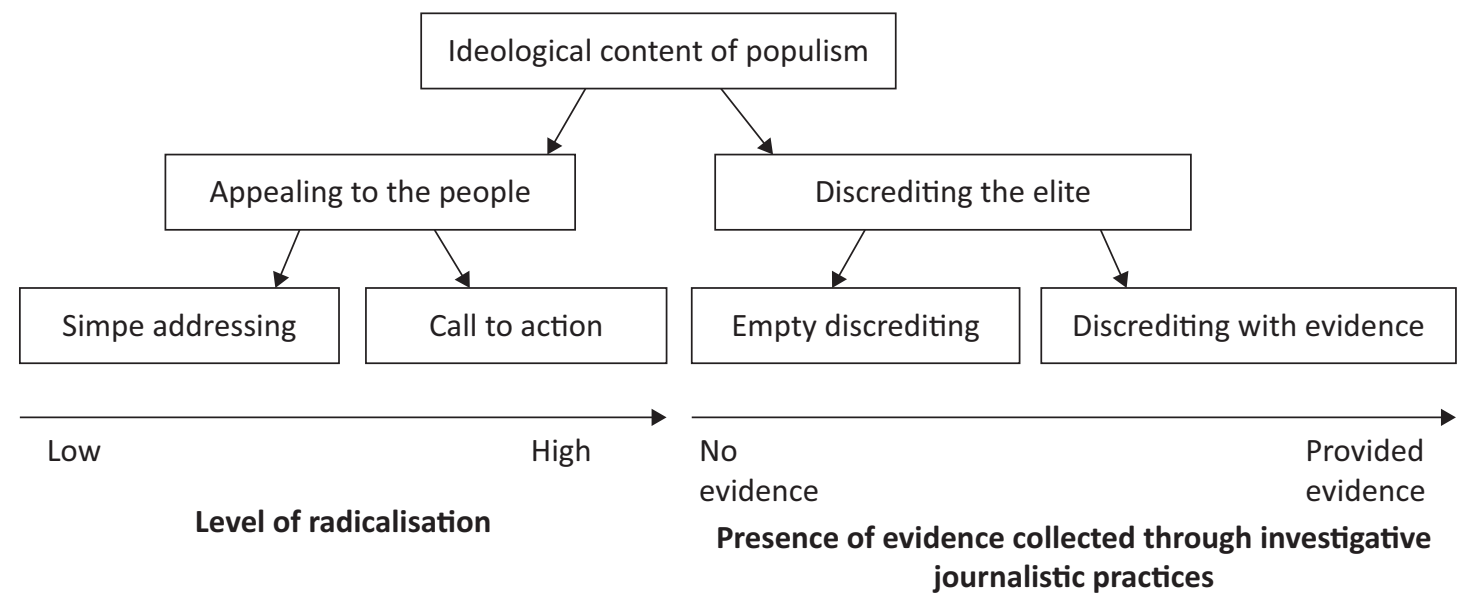

Figure 1. Ideological elements of populism in Navalny's videos: Categories for coding.

Table 1. Types of populisms in Navalny's narration based on the combination of populism sub-categories.

\begin{tabular}{lll}
\hline Discrediting the elite/appeal to 'the people' & Simple addressing & Call to action \\
\hline Empty discrediting & Superficial populism (102) & Radical populism (57) \\
Discrediting with evidence & Investigative populism (47) & Advocacy populism (11) \\
\hline
\end{tabular}

Note: The number in brackets represents the number of combinations that appeared in Navalny's video excerpts. 


$$
n=\frac{(N-1)(S E)^{2}+P Q N}{(N-1)(S E)^{2}+P Q}
$$

Figure 2. The formula for the calculation of sub-sample for reproducibility test. Note: $n=$ the size of sub-sample; $N=$ total number of the whole sample; $P=$ desirable level of agreement; $S E=$ standard error; $Q=1-P$.

The formula depended on three key factors of intercoder agreement: the total number of text components to be coded, the desired level of agreement and the confidence level desired for the test. $N=331$ for this research stage, $S E=0,03$ is determined by the level of significance (0.95) and the z-score associated (using the one-tailed version) is 1.64 . The desirable level of agreement was 0.7 , with the level of confidence being 0.8 . The calculated sub-sample with these parameters was 89 . Therefore, 89 main excerpts out of 331 were chosen randomly using the online Research Randomizer (Social Psychology Network, n.d.).

The level of agreement was measured for each one of the four categories of populist content. The results of the coding process were transferred to SPSS to calculate Krippendorff's alpha (2004). The standards for data reliability, according to Krippendorff (2004), are that a score between $\alpha=0.667$ to $\alpha=0.800$ is considered as substantial, and a score above $\alpha=0.800$ is considered as perfect agreement. Considering that I explored the ambiguous phenomenon of populism (which had many interpretations), I aimed at reaching a score of $\alpha=0.750$. In all four categories, the inter-coder agreement reached was as follows: 'simple addressing' (0.7943), 'call to action' (0.8825), 'empty discrediting' (0.7802), and 'discrediting with evidence' $(0.7700)$. This means that the data is reliable and reproducible.

Having four variables (categories) for the analysis resulted in the formation of four combinations of populism categories. I named these according to Table 1 and counted them in NVivo.

\subsection{Overview}

I constructed the quantitative data's meaning through the qualitative procedures of close reading of the research's sub-sample. I looked at how Navalny addressed 'the people,' what he called these people to do, how he discredited the elite, and what evidence he used to discredit them. Each type of populism (as per Table 1) appeared in a different number of excerpts. The intensive nature of the qualitative part of the analysis made it impractical to analyse all 331 excerpts. I pre-defined the size of the purposive sample for close reading procedures as follows: 'superficial' populism (20 excerpts), 'radical' populism (10 excerpts), 'investigative' populism (10 excerpts), and 'advocacy' populism (10 excerpts). The excerpts were chosen through random sampling using the web-tool Research Randomizer (Social Psychology Network, n.d.). The summaries of these excerpts were used to develop a deeper understanding of Navalny's populist narrative and what it means for Russia's broader PC ecosphere.

\section{Four Types of Populism in Navalny's YouTube Narration}

This section will look closely at the main characteristics of these populist excerpts, including their meaning, topics, and structure, to define what each type of populism means in Navalny's narration.

\subsection{Superficial Populism}

'Superficial' populism is located at 'the surface' of Navalny's narration. The excerpts do not require a lot of effort to create by their narrators and investigators. Navalny does not provide evidence of crimes committed by the elite, or motivate people to engage in activism through radical appeals in these excerpts. In some ways, this could also be referred to as 'passive' populism, which does not require specific actions from the narrator or the audience.

These excerpts can link other parts of narration or serve as the introduction to the investigations or radical appeals. 20 excerpts in the sample are short in length; on average, 197 words each. The longest excerpt within the sample is 738 words, whereas the shortest is 35 words. They are usually located at the beginning and/or in the middle of narration. The themes of these excerpts are also diffused and cover topics from corruption to elections. The elite's critique has a personalised and diffused nature. It targets many different actors of the elite-from executive power to corrupt media representatives.

In these excerpts, there is a simple level of association of Navalny with 'the people' through the words 'we' and 'us,' which may indicate Navalny's intention to build one collective identity opposed to the elite. These principles lie at the heart of populist ideology, and they can explain the dominance of these excerpts in Navalny's populist narration. This also reflects the fact that this populism may be communicated in as little as one or several words, simply by calling someone a 'thief,' a 'liar,' or using personal pronouns. The example of the superficial excerpt criticising main Navalny's rival, Putin, reads as follows: 
Thank you, everyone, who participated, organised, and helped. I congratulate you with successful (protest) action in number and geographical scope. We showed that even if Russia is entering the fifth term of Putin, here, there are many of those who are not ready to turn into zombies or became a slave of the self-proclaimed tzar. (Navalny, 2018a)

\subsection{Investigative Populism}

In these excerpts, Navalny uses investigative journalistic tools to discredit the elite, providing textual references to the evidence of their crimes collected through journalistic practices. 'Investigative' populism excerpts are of medium length compared to other excerpts: the shortest excerpt is 116 words, whereas the longest excerpt is 733 words. The average excerpt in the sample is 316 words. Usually, they are located in the middle of the narration.

Navalny uses many anti-corruption symbols in the texts, including luxurious properties and items that he claims officials possess. He provides examples of the corruption crimes and nepotism of the elites, referring in his claims to a substantial base of journalistic evidence. He employs social media data, photos, interviews, people's CVs, and other forms of journalistic evidence. He mentions these forms of evidence in his narration, but the visual presence of such evidence was not analysed in this research.

The most referred form of evidence in this sample was the drone video footage. Video is one of the trustworthy forms of evidence for IJ (Ettema \& Glasser, 1984). Drone footage can be one of the most accessible journalistic instruments available to Navalny and his team; it also requires advanced skills of drone journalism as outlined in his videos:

But today I have something new for you. Many of you, of course, remember that recently we bought a new cool quadcopter and as soon as it arrived we started to figure out how it works, started to learn how to use it, and finally we did a test flight. We decided not to send it into a 'foreign' trip or for a super difficult task, but just to test it on the 'old object,' which we shoot before but only with photos. (Navalny, 2018b)

Even based on this small sample, it is evident that Navalny usually uses modern and digital technologieswhen investigating the elites' purported crimes-due to their effectiveness, comparatively low cost, as well as relevance to the YouTube medium. Curating, processing and presenting the data for his investigation may require significantly more time and work on behalf of Navalny and his team-this is a characteristic constitute of IJ. The simplicity of addressing the people in these excerpts presupposes associating the narrator with the audience through the personal pronouns and nouns, as in 'superficial' populism. The discrediting attacks of the elite in these excerpts have a personalised character and target particular people, such as the former PM Medvedev.

\subsection{Radical Populism}

'Radical' populism excerpts contain characteristics of citizen activism propagated by Navalny. These excerpts greatly vary in their text length within the sample: from 89 words to 1,000 words. The approximate average length of the excerpts is 400 words. The excerpts seemed to be located towards the end of his narrationemphasising the strong message or an appeal directed to 'the people.'

Most of these excerpts were connected to elections. They form a crucial part of Russia's political ecosystem, which both the ruling elite and the non-systemic opposition take seriously. Within the same electoral period in which the sample was taken, Navalny invites people to first participate and vote in elections, and then to boycott them-just as when he was barred from the 2018 election. Ironically, both calls intend to safeguard the democratic meaning of this institution.

This small sample of excerpts also contains different forms of 'offline' and 'online' calls to action. In his 'offline' call, Navalny invites people to: boycott the elections (4), go to peaceful protests (3), become observers at the elections (2), put down a signature for his nomination to the presidential elections (2), as well as other actions (1). In his 'online' call, Navalny invites people to subscribe to his YouTube channel (4), share the video (4), as well as other online actions (2). The 'offline' calls are mostly associated with political participation in elections and protests. The 'online' calls are an everyday form of digital action with political meaning which users can exercise in Russia without fear of persecution typical to the Russian regime:

Take this video with the investigation and send it to everyone, literally to everyone, post it everywhere where you can. This is our war of spreading against their blocking, and we should win in this war. Subscribe to our channel, we tell the truth here. (Navalny, 2018c)

\subsection{Advocacy Populism}

'Advocacy' populism excerpts are located at the intersection of digital activism and IJ. Some IJ practices can help to discredit the elite, whereas digital activism sometimes contains an appeal to 'the people,' mostly in radical forms. Advocacy populism excerpts are usually lengthy (on average 1,064 words each) and located at the end of narration, or they are full text transcripts of sole YouTube videos.

The excerpts were the following parts of investigations into the elites' corruption. They describe luxurious properties, the elites' nepotism, and provide evidence of the elite's corruption crimes. These excerpts contain el- 
ements of drone journalism; enabling a birds-eye view of officials' otherwise inaccessible properties. This has a dramatic effect on YouTube users, who in all likelihood have not seen this footage on any mainstream formats in Russia.

However, Navalny does not only engage YouTube users in his investigative story-he wants his audience to act. He motivates people to act both 'online' and 'offline' in these excerpts:

On the 28th of January, I urge you all to participate in the protest action in your city. Not for me, not about me, but to protect your own right to participate in the country's life, the right at least once in six-year time to ask from the authorities: 'So where did you, bastards take our oil money?' Subscribe to our channel-we tell the truth here. (Navalny, 2018d)

Some of his efforts, for example, the investigation into the PM's corruption - his most popular video with 30 million views (in June 2020)-led to mass protests organised by Navalny in Russia in 2017. Interestingly, the concentration of released videos with advocacy excerpts occurred before and during these protests. Navalny published his investigation about the former PM on March 2, 2017, which itself consisted of two advocacy excerpts. Then, from this date until June 15, 2017, he published a further five videos with 'advocacy' excerpts. During this time period, Navalny organised two major anti-corruption protests connected with the investigation on March 26 and June 12 in the same year, which were claimed to be the biggest protests since those occurring in 2011-2012 (Pinchuk \& Shurmina, 2017).

In sum, there is a strong and substantive message in these parts of the videos which contains several calls to action, general and personalised attacks of the elite, and evidence of elitist corruption crimes collected through IJ practices-which not only motivate people to act 'online' but sometimes can potentially encourage people to participate in real, physical protests (as was seen in 2017).

\section{Conclusion}

This research has illuminated some of the major communication strategies that non-systemic opposition representatives use to stay 'afloat' in the autocratic political environment and to overcome political censorship and limited media freedom. From a broader perspective, the analysis of Navalny's communication helps researchers to determine whether there is 'luft' (from German 'air') for spreading anti-establishment discourses in censored Russian PC, and discern what communication strategies types of non-systemic opposition in Russia favour its fight for survival in the public sphere.

In Russia's current political climate where dissident elements of society are silenced, threatened, harassed, or even eliminated, Navalny's project marks a unique change of pace in Russian opposition history in the last decade. Many of his anti-corruption colleagues in the 2010s, who were active online in this area, disappeared from the Russian public sphere due to harassment (Etling et al., 2010; Knobel \& Sanders, 2012).

In Navalny's case, we see the use of digital populist communication strategies to challenge Putin's elite, which has held power for 20 years. Navalny's opposition populism has distinctive features within Russian populism in particular, and populism in general-combining IJ and digital activism practices in his narration. Navalny's populist style not only demonstrates evidence of the elite's crimes but also invites citizens to participate in politics. Sometimes people react to this call, as was seen in protests of 2017 inspired by Navalny's YouTube documentary. By providing his audience with a variety of political actions in his narration, he shows pathways to political change in a country usually resistant to them. Some of the pathways are easy to implement with one click, while others involve 'physical' political actions.

YouTube's status as the most popular social media platform in Russia (Statista, 2019) provides Navalny with a space for his anti-establishment sentiments. The platform seems to negotiate with censorship and regulatory bodies. Therefore, it can leave space for anticorruption investigations such as Navalny's. For instance, it did not delete Navalny's major resonant investigations, and these are still available to YouTube users (Agora, 2019). In so doing, YouTube aids the preservation of anticorruption and anti-establishment discourses in Russia.

Navalny's narration on YouTube is consonant with the notion of cyber-populism (Gerbaudo, 2017). Navalny is a populist who claims a "bottom-up recuperation and reclamation of democracy and political institutions by ordinary citizens" (Gerbaudo, 2017, p. 485). He offers a more authentic political participation than the ruling elite allows. His communication brings diversity to a public sphere monopolised by pro-government discourses. His videos are highly viewed, accessible, and can be easily shared via the platform.

It is still doubtful and requires further investigation, whether his discourse can bring about the longlasting realisation of protest potential in Russia. Having witnessed the tragic impact of revolutions in the last century, and more specifically political and economic crises in the 1990s, the Russian people became increasingly hesitant to participate in protests with economic (1998-2018) or political (2009-2018) demands in the following two decades, according to Levada's (2020) survey. Despite the noticeable intensification of protest potential in the last three years (Levada, 2020), the establishment-afraid of protests and radical changes to the political system-has also been effective in countering the protests. The introduction of restrictive laws on mass gatherings as in 2012, the administrative bans on local protests, or the mass arrests and harassment of protesters (including Navalny himself) continue to hamper the coherence and mass character of Russia's protest movement. 
Navalny has since become an example for other activists-mostly his associates-to resist authoritarian rule, activate the mobilising potential of citizens, and advocate their political rights. This was evident during the 2019 protests surrounding Moscow's municipal election. Three of Navalny's associates-Sobol, Yashin, and Zhdanov-were barred from registration in the election, and organised mass protests in Moscow using digital instruments as part of their repertoire. Previously, it was shown that his associates used the same visual style as Navalny in their YouTube videos (Glazunova, 2020). The events of this kind require further investigation into activists' narrations, to better assess the applicability of Navalny's populist template within the broader phenomenon of Russian non-systemic opposition.

\section{Acknowledgments}

I would like to thank the Digital Media Research Centre at the Queensland University of Technology (QUT), Brisbane, Australia for providing me with the opportunity to undertake a PhD research and sponsoring my research activities, and the Research Office of QUT for awarding me a Postgraduate Research Award (2017-2020) to support my studies. Individually, I would like to thank my supervisors at QUT, Professor Clive Bean and Associate Professor Angela Romano, for their insightful guidance during my PhD degree. Finally, my words of appreciation go to Dr. Aljosha Karim Schapals (QUT) and Maryline Kassab (University of Queensland) for their invaluable editing contributions to this article.

\section{Conflict of Interests}

The author declares no conflict of interests.

\section{References}

Agora. (2018). Svoboda Interneta 2017: polzuchaya kriminalizatsiya [The freedom of the Internet 2017: Slithering criminalization]. Agora. Retrieved from https://www.agora.legal/articles/Doklad-

Mezhdunarodnoi-Agory-«Svoboda-interneta-2017polzuchaya-kriminalizaciya»/11

Agora. (2019). Doklad mezdunarodnoi Agory 2018; Svoboda interneta 2018: delegirovanie repressii [The report of International Agora: The freedom of the Internet and delegation of the repression]. Agora. Retrieved from https://agora.legal/articles/DokladMezhdunarodnoi-Agory-«Svoboda-interneta-2018delegirovanie-repressiy»/18

Appelgren, E., \& Nygren, G. (2014). Data journalism in Sweden: Introducing new methods and genres of journalism into 'old' organizations. Digital Journalism, 2(3), 394-405. https://doi.org/10.1080/ 21670811.2014.884344

Becker, J. (2004). Lessons from Russia: A neoauthoritarian media system. European Journal of Communication, 19(2), 139-163.

Blumler, J. G. (2013). The fourth age of political communication: Keynote address delivered at a Workshop on Political Communication Online, the Free University of Berlin, September 12. Scribd. Retrieved from https://www.scribd.com/document/ 337580226/Blumler-The-Fourth-Age-of-PoliticalCommunication-2013

Bonikowski, B., \& Gidron, N. (2016). The populist style in American politics: Presidential campaign discourse, 1952-1996. Social Forces, 94(4), 1593-1621. https:// doi.org/10.1093/sf/sov120

Burgess, J., \& Green, J. (2018). YouTube: Online video and participatory culture (2nd ed.). Cambridge: Polity Press.

Carson, A. (2019). Investigative journalism, democracy and the digital age. New York, NY: Routledge.

De Burgh, H. (2008). Investigative journalism. Abingdon: Routledge.

de Vreese, C. H., Esser, F., Aalberg, T., Reinemann, C., \& Stanyer, J. (2018). Populism as an expression of political communication content and style: A new perspective. The International Journal of Press/Politics, 23(4), 423-438. https://doi.org/ 10.1177/1940161218790035

Engesser, S., Ernst, N., Esser, F., \& Büchel, F. (2017). Populism and social media: How politicians spread a fragmented ideology. Information, Communication \& Society, 20(8), 1109-1126. https://doi.org/10.1080/ 1369118X.2016.1207697

Etling, B., Alexanyan, K., Kelly, J., Farris, F., \& Gasser, U. (2010). Public discourse in the Russian blogosphere: Mapping RuNet politics and mobilization. The Berkman Center for Internet and Society Research Publication Series. Retrieved from http://nrs.harvard.edu/ urn-3:HUL.InstRepos:8789613

Ettema, J. S., \& Glasser, T. L. (1984). On the epistemology of investigative journalism. Paper presented at the 67th Annual Meeting of the Association for Education in Journalism and Mass Communication, Gainesvile, FL.

Fairclough, N. (2001). Language and power. Harlow: Pearson Education.

FOM. (2018). Kak chasto I zachem lyudi smotryat televisor [How often and why people watch TV]. FOM. Retrieved from https://fom.ru/SMI-i-internet/14029

Gel'man, V. (2013). Cracks in the wall: Challenges to electoral authoritarianism in Russia. Problems of PostCommunism, 60(2), 3-10.

Gel'man, V. (2015). Political opposition in Russia: A troubled transformation. Europe-Asia Studies, 67(2), 177-191. https://doi.org/10.1080/09668136. 2014.1001577

Gerbaudo, P. (2017). From cyber-autonomism to cyberpopulism: An ideological history of digital activism. TripleC: Communication, Capitalism \& Critique, 15(2), 477-489.

Gerbaudo, P. (2018). Social media and populism: An 
elective affinity? Media, Culture \& Society, 40(5), 745-753. https://doi.org/10.1177/0163443718772 192

Glazunova, S. (2020). Digital media as a tool for nonsystemic opposition in Russia: A case study of Alexey Navalny's populist communication on YouTube (Unpublished doctoral dissertation). Queensland University of Technology, Brisbane, Australia.

Houston, B. (2010). The future of investigative journalism. Daedalus, 139(2), 45-56. https://doi.org/ 10.1162/daed.2010.139.2.45

Inglehart, R., \& Norris, P. (2016). Trump, Brexit, and the rise of populism: Economic have-nots and cultural backlash (Harvard Kennedy School Faculty Research Working Paper Series). Cambridge, MA: Harvard Kennedy School. Retrieved from https://research. hks.harvard.edu/publications/workingpapers/ Index.aspx

Jacobs, K., Sandberg, L., \& Spierings, N. (2019). Twitter and Facebook: Populists' double-barrelled gun? Paper presented at the International Communication Association, Washington, DC.

Jagers, J., \& Walgrave, S. (2007). Populism as political communication style: An empirical study of political parties' discourse in Belgium. European Journal of Political Research, 46(3), 319-345. https://doi.org/ 10.1111/j.1475-6765.2006.00690.x

Kaplan, A. M., \& Haenlein, M. (2010). Users of the world, unite! The challenges and opportunities of social media. Business Horizons, 53(1), 59-68.

Knobel, B., \& Sanders, J. (2012). Samizdat 2.0: The Dymovsky case and the use of streaming video as a political tool in Contemporary Russia. International Journal of E-Politics, 3(1), 26-41.

Kolesnikov, A., Kortunov, A., \& Snegovaya, M. (2018). Ssha, Evropa, Rossiya: Takie raznye populismy [USA, Europe, Russia: Such different populisms]. Carnegie. Retrieved from http://carnegie.ru/2018/05/21/ruevent-6896

Krippendorff, K. (2004). Content analysis: An introduction to its methodology (2nd ed.). Thousand Oaks, CA: Sage.

Krippendorff, K. (2012). Content Analysis: An introduction to its methodology ( 3 rd ed.). Thousand Oaks, CA: Sage.

Laclau, E. (2005). On populist reason. London: Verso.

Laclau, E., \& Mouffe, C. (1985). Hegemony and social strategy: Towards a radical democratic politics. London: Verso.

Levada. (2017). Protesty i Navalny [Protests and Navalny]. Levada. Retrieved from https://www.levada.ru/ 2017/07/17/protesty-i-navalnyj

Levada. (2020). Otsenka tekuschego polozheniya del $v$ strane [The assessment of current situation in the country]. Levada. Retrieved from https://www. levada.ru/indikatory/polozhenie-del-v-strane

McNair, B. (2011). An introduction to political communication (5th ed.). Abingdon: Routledge.
Moffitt, B., \& Tormey, S. (2014). Rethinking populism: Politics, mediatisation and political style. Political Studies, 62(2), 381-397.

Mudde, C. (2004). The populist zeitgeist. Government and Opposition, 39(4), 541-563. https://doi.org/ 10.1111/j.1477-7053.2004.00135.x

Navalny, A. (2018a, May 6). Navalnyi ob aktsii 5-go maya [Navalny about the rally on the 5th of May] [Video file]. Retrieved from https://youtu.be/jnjSquL9cW8

Navalny, A. (2018b, March 6). Dvorets na kotoryi zaprescheno smotret [The palace that we cannot look at] [Video file]. Retrieved from https://youtu.be/ rbRoZyuOijk

Navalny, A. (2018c, February 12). Rassledovanie objavleno zapretnym [The investigation declared forbidden] [Video file]. Retrieved from https://youtu.be/ Jv0fp5KpKhs

Navalny, A. (2018d, January 15). A kudadeis nashi neftyanye dengi? [Where did our oil money go?] [Video file]. Retrieved from https://youtu.be/ fLhYofZ1SLk

Newman, N., Fletcher, R., Kalogeropoulos, A., \& Nielsen, R. K. (2019). Reuters Institute digital news report 2019. Oxford: Reuters Institute for the Study of Journalism. Retrieved from https://reutersinstitute. politics.ox.ac.uk/sites/default/files/inline-files/ DNR_2019_FINAL.pdf

Pauwels, T. (2011). Measuring populism: A quantitative text analysis of party literature in Belgium. Journal of Elections, Public Opinion \& Parties, 21(1), 97-119. https://doi.org/10.1080/17457289.2011.539483

Pinchuk, D., \& Shurmina, N. (2017, March 26). Russian police detain opposition leader, hundreds of protesters. Reuters. Retrieved from https://www. reuters.com/article/us-russia-protestsidUSKBN16X0G8

Rai, S. M. (2015). Political performance: A framework for analysing democratic politics. Political Studies, 63(5), 1179-1197.

Repnikova, M. (2018). Contesting the state under authoritarianism: Critical journalists in China and Russia. Comparative Politics, 51(1), 41-60.

Repucci, S. (2019). Freedom and the media: A downward spiral. Freedom House. Retrieved from https://freedomhouse.org/report/freedom-media/ freedom-media-2019

Riffe, D., Lacy, S., \& Fico, F. (2014). Analyzing media messages: Using quantitative content analysis in research (3rd ed.). New York, NY: Routledge.

Schrape, J. F. (2016). Social media, mass media and the 'public sphere': Differentiation, complementarity and co-existence (SOI Discussion Paper 2016-01). Stuttgart: University of Stuttgart. Retrieved from https://www.ssoar.info/ssoar/handle/document/ 48295

Social Psychology Network. (n.d.). Homepage. Research Randomizer. Retrieved from https://www. randomizer.org 
Spaiser, V., Chadefaux, T., Donnay, K., Russmann, F., \& Helbing, D. (2017). Communication power struggles on social media: A case study of the 2011-12 Russian protests. Journal of Information Technology \& Politics, 14(2), 132-153.

Statista. (2019). Most used social media platforms in Russia as of third quarter of 2019, by penetration rate. Statista. Retrieved from https://www. statista.com/statistics/284447/russia-socialnetwork-penetration/

Stetka, V., \& Örnebring, H. (2013). Investigative journalism in Central and Eastern Europe: Autonomy, business models, and democratic roles. The International Journal of Press/Politics, 18(4), 413-435. https://doi. org/10.1177/1940161213495921

Sumiala, J. M., \& Tikka, M. (2013). Broadcast yourselfglobal news! A netnography of the 'Flotilla' news on YouTube: Broadcast yourself-global news! Communication, Culture \& Critique, 6(2), 318-35. https://doi. org/10.1111/cccr.12008

Waisbord, S., \& Amado, A. (2017). Populist communication by digital means: Presidential Twitter in Latin America. Information, Communication \& Society, 20(9), 1330-1346. https://doi.org/10.1080/ 1369118X.2017.1328521

White, S., \& McAllister, I. (2014). Did Russia (nearly) have a Facebook revolution in 2011? Social media's challenge to authoritarianism. Politics, 34(1), 72-84.

\section{About the Author}

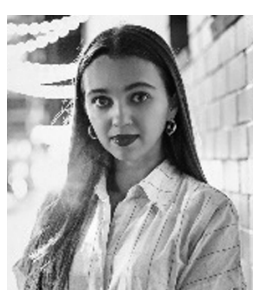

Sofya Glazunova is a Postdoctoral Research Fellow in the Digital Media Research Centre at the Queensland University of Technology, Brisbane, Australia. She specialises in political communication, Russian politics, digital media, and misinformation, as well as alternative and investigative journalism. In her postdoctoral research, she focuses on how pro-government media outlets adapt to a global digital environment and utilise instruments of propaganda via social media. 